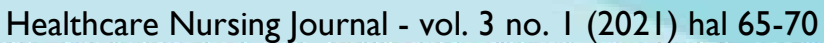

\section{HUBUNGAN KEBIASAAN MEROKOK ANGGOTA KELUARGA DENGAN KEJADIAN ISPA PADA BALITA UMUR 1-5 TAHUN}

\author{
Gunawan Irianto', Arena Lestari², Marliana³ \\ ${ }^{123}$ FIKes Universitas Muhammadiyah Pringsewu
}

\section{Article Information}

Received: Desember 3th, 2020

Revised: January 1th, 2021

Available online: January, 2021

\section{Keywords}

ISPA, Kebiasaan Merokok, Anak-anak

\section{Correspondence}

Phone: (+62) 82372955590

E-mail:

gunawanirianto@umpri.ac.id

\section{PENDAHULUAN}

Meningkatnya umur harapan hidup dan perubahan struktur umur penduduk kearah usia tua serta perubahan pola dan gaya hidup menyebabkan terjadinya transisi demografi epidemiologi, yang ditandai dengan masih tingginya penyakit infeksi dan meningkatnya penyakit non infeksi (DINKES, 2016). Salah satu penyakit infeksi yang sering terjadi adalah Infeksi saluran pernapasan atas (ISPA). Penyakit yang disebabkan oleh virus ini banyak menyebar baik dikalangan anak-anak maupun dewasa. Penyakit ISPA ini tidak hanya menjadi masalah di Negara berkembang namun juga menjadi masalah global di negara lain. Hal ini dapat dilihat dari angka kematian balita menurut WHO memperkirakan \pm 
13 juta anak balita di dunia meninggal dan kematian tersebut terdapat di Negara berkembang di Asia dan Afrika seperti: India (48\%), Indonesia (38\%), Ethiopia (4,4\%), Pakistan $(4,3 \%)$, China (3,5\%), Sudan (1,5\%), dan Nepal (0,3\%). Dimana ISPA merupakan salah satu penyebab utama kematian dengan membunuh \pm 4 juta dari \pm 13 juta anak balita setiap tahun dan pada tahun 2016 WHO melaporkan hampir 6 juta anak meninggal dunia dan $16 \%$ dari jumlah tersebut disebabkan oleh ISPA.

ISPA dipengaruhi banyak faktor, salah satunya yaitu faktor lingkungan. Faktor lingkungan yang dapat menjadi penyebab ISPA diantaranya kondisi fisik rumah, kepadatan hunian rumah, polusi udara seperti asap rokok, asap pembakaran dirumah tangga, pembakaran sampah, gas buangan sarana trnsportasi, gas buangan industry, kebakaran hutan dan lain-lain. Dari beberapa faktor tersebut diatas yang dapat meningkatkan resiko terjadinya ISPA salah satunya adalah faktor lingkungan yaitu pencemaran udara seperti paparan asap rokok atau kebiasaan keluarga yang merokok.

Merokok merupakan tindakan yang berbahaya karena menurut WHO rokok merupakan zat adiktif yang memiliki 4000 elemen dimana 200 elemen didalamnya berbahaya bagi kesehatan tubuh (Milo, Ismanto, \& Kallo, 2015). Asap rokok mengandung ribuan bahan kimia beracun dan bahan-bahan yang dapat menimbulkan kanker (karsinogen). Bahkan bahan berbahaya dan racun dalam rokok tidak hanya mengakibatkan gangguan kesehatan pada orang yang merokok, namun juga kepada orang-orang di sekitarnya yang tidak merokok yang sebagian besar adalah bayi, anak-anak dan ibu-ibu yang terpaksa menjadi perokok pasif, oleh karena ayah atau suami mereka merokok di rumah. Kebiasaan merokok di dalam rumah dapat meningkatkan resiko terjadinya ISPA sebanyak 2,2 kali (Suryono, 2010).

Indonesia sendiri Pada tahun 2018 prevalensi ISPA menurut diagnosis tenaga kesehatan mencapai 4,4\% dari 34 provinsi di Indonesia. Sedangkan prevalensi berdasarkan diagnosis Nakes dan gejala menurut provinsi mencapai 9,3 \% (KEMENKESRI, 2018). Pada tahun 2019 Dinas
Kesehtan Provinsi Lampung melaporkan angka kematian balita akibat ISPA mencapai $17 \%$. Cakupan penemuan ISPA dengan kategori Pneumonia di provinsi Lampung mencapai 36,48 \% dengan $8,31 \%$ di sumbangkan oleh Kabupaten Tanggamus (DINKES, 2019).

Berdasarkan hasil prasurvei di Puskesmas Talangpadang didapatkan data skunder bahwa dalam periode 3 tahun terahir kasus ISPA selalu menduduki peringkat pertama dari 10 besar jenis penyakit terbanyak di rawat jalan yaitu mencapai $13,4 \%$ - $21 \%$ setiap bulannya dengan jumlah kunjungan mencapai \pm 6.400 kasus pada tahun 2018 namun pada tahun 2019 turun menjadi \pm 4500 kasus,

Berdasarkan penelitian-penelitian yang ada dan data yang ditemukan maka penulis tertarik untuk mengetahui apakah ada hubungannya antara kebisaan merokok anggota keluarga dengan kejadian ISPA di wilayah kerja Puskesmas Talangpadang

\section{METODE}

Penelitian ini menggunakan metode deskriptif analitik dengan pendekatan cross sectional, di lakukan di Puskesmas Talangpadang. Penelitian ini dilaksanakan dari bulan Februari-Mei 2020, sasaran dalam penelitian ini adalah seluruh pasien ISPA berumur 1-5 tahun yang berkunjung ke Puskesmas Talangpadang pada tanggal 9-25 april 2020 berjumlah 66 orang. Data yang digunakan dalam penelitian ini adalah data primer dengan pengambilan sampel menggunakan tehnik consecutive sampling. Instrument yang digunakan adalah kuesioner. Jenis pertanyaan yang

\section{HASIL DAN PEMBAHASAN}

Tabel.1 Distribusi frekuensi berdasarkan umur dan jenis kelamin responden diwilayah kerja Puskesmas Talangpadang

\begin{tabular}{lcc}
\hline Umur & Frekuensi & Peresntase \\
\hline $\begin{array}{l}\text { Toddler }(1- \\
\left.2,5^{\text {th }}\right)\end{array}$ & 35 & 53 \\
$\begin{array}{l}\text { Prasekolah } \\
\left(2,6-5^{\text {th }}\right)\end{array}$ & 31 & 47 \\
\hline
\end{tabular}




\begin{tabular}{lll}
\hline Jumlah & 66 & 100 \\
\hline $\begin{array}{l}\text { Jenis Kelamin } \\
\text { Laki-laki }\end{array}$ & 39 & 59,1 \\
Perempuan & 27 & 40,9 \\
\hline Jumlah & 66 & 100 \\
\hline
\end{tabular}

Tabel.2 Distribusi frekuensi berdasarkan kejadian ISPA diwilayah kerja Puskesmas Talangpadang

\begin{tabular}{lll}
\hline Kejadian ISPA & Frekuensi & persentase \\
\hline ISPA Ringan & 55 & 83,3 \\
ISPA Sedang & 11 & 16,7 \\
\hline Jumlah & $\mathbf{6 6}$ & $\mathbf{1 0 0}$ \\
\hline
\end{tabular}

Tabel.3 Distribusi frekuensi berdasarkan Kebiasaan merokok diwilayah kerja Puskesmas Talangpadang

\begin{tabular}{lcc}
\hline $\begin{array}{l}\text { Kebiasaan } \\
\text { Merokok }\end{array}$ & Frekuensi & Persentase \\
\hline Tidak merokok & 8 & 12,1 \\
Perokok Ringan & 50 & 75,8 \\
Perokok sedang & 8 & 12,1 \\
\hline Jumlah & 66 & $\mathbf{1 0 0}$ \\
\hline
\end{tabular}

Tabel.2 Hubungan kebiasaan merokok anggota keluarga dengan kejadian ISPA diwilayah kerja Puskesmas Talangpadang

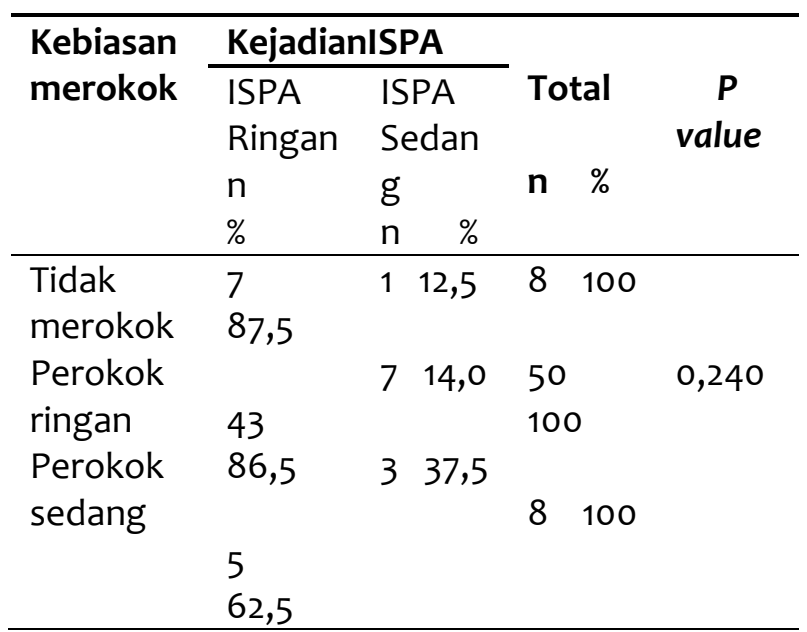

\begin{tabular}{llll}
\hline Jumlah & 55 & 1116,7 & 66 \\
& 83,3 & & 100 \\
\hline
\end{tabular}

Penelitian ini dilakukan di Puskesmas Talangpadang dengan jumlah sampel sebanyak 66. Responden yang diambil dengan teknikconsecutive sampling.

Berdasarkan hasil penelitian didapatkan bahwa karakteristik responden berdasarkan usia sebagian besar adalah berusia toddler 1-2,5 tahun berjumlah 35 responden (53\%) sedangkan usia prasekolah 2,6-5 tahun berjumlah 31 (47\%). Jenis kelamin responden yang menderita ISPA sebagian besar adalah laki-laki berjumlah 39 orang (59,1\%)

Berdasarkan hasil penelitian didapatkan bahwa kejadian ispa anak umur 1-5 tahun terbanyak adalah ISPA ringan sebesar 83,3 persen dengan jumlah 55 responden dan untuk ISPA sedang berjumlah 11 responden dengan persentase 16,7 persen.

Kejadian ISPA dapat disebabkan berbagai faktor diantaranya faktor individu sepeti kebutuhan gizi, berat badan lahir, dan faktor lingkungan seperti pencemaran udara diantaranya disebabkan oleh paparan asap rokok, ventilasi rumah dll ( Maryunani,2010).

Berdasarkan hasil penelitian bahwa sebagian besar dari responden mempunyai anggota keluarga yang memiliki kebiasaan merokok ringan berjumlah 50 responden $(75,8 \%)$, tidak memiliki kebiasaan merokok 8 responden (12,1\%), merupakan perokok sedang 8 responden (12,1\%).

Asap rokok yang di hisap oleh perokok pasif sama bahayanya dengan rokok dan asap yang dihisap oleh perokok aktif. Dirumah resiko perokok pasif bagi anak2 juga besar, penyakit yang mungkin dapat terjadi adalah gangguan pernapasan ( asma, bronkistis dan pneumonia) (Fajar \& Pustaka, 2011).

Berdasarkan hasil uji statistik diketahui bahwa nilai $p$-value yaitu $0,240>0,05$ sehingga $\mathrm{Ha}$ ditolak dimana syarat Ha diterima nilai p-value < 0,05 maka hal ini menunjukkan bahwa tidak ada hubungan antara kebiasaan merokok anggota keluarga dengan kejadian ISPA pada anak umur 
1-5 tahun di wilayah kerja Puskesmas Talangpadang.

Hasil penelitian bertolak belakang dengan hasil penelitian yang di lakukan oleh Milo Salma 2015, hasil penelitian menunjukkan bahwa ada hubungan antara kebiasaan merokok dengan kejadin ISPA pada balita dengan nilai $p$-value 0,002, namun sejalan dengan hasil penelitian yang dilakukan oleh (Hayati, 2017) dengan judul penelitian Hubungan konsentrasi PM10 faktor lingkungan dalam rumah dengan keluhan infeksi saluran pernapasan akut (ISPA) pada balita di Puskesmas Rawa Terate kecamatan Cakung 2017. Hasil penelitian menunjukkan bahwa tidak ada hubungan antara keluarga yang merokok dengan kejadian ISPA pada balita dengan nilai $p$-value 0,556 , begitu pula penelitian yang dilakukan oleh Yovita Vivi 2017 bahwa hasil uji chi-square diketahui nilai p-value 0,959 menunjukkan bahwa tidak ada hubungan yang bermakna antara paparan asap rokok dengan terjadinya ISPA pada balita di Klinik Pratama Gotong Royong Surabaya.

Hasil yang sama pula dilakukan oleh (Fillacano, 2019) dalam penelitiannya yang berjudul Hubungan lingkungan dalam rumah terhadap ISPA pada balita di kelurahan Ciputat Kota Tangerang tahun 2013 bahwa diketahu hasil uji statistic menunjukkan bahwa tidak ada hubungan kebiasaan merokok penghuni rumah terhadap ISPA pada balita di kelurahan Ciputat dengan nilai $p$-value 0,409. Secara umum terdapat 3 (tiga) faktor resiko terjadinya ISPA, yaitu faktor lingkungan, faktor individu, serta faktor perilaku. Faktor lingkungan diantaranya pencemaran udara dalam rumah (asap rokok), ventilasi rumah. Faktor individu sepreti kebutuhan gizi, berat badan lahir,dan status imunisasi ( Maryunani,2010 ).

Menurut peneliti tidak adanya hubungan kebiasaan merokok anggota keluarga dengan kejadian ISPA baik ringan ataupun sedang pada anak umur 1-5 tahun di UPT Puskesmas Talangpadang dapat diesbabkan karena anak dijauhkan pada saat ada anggota keluarga yang merokok. Kejadian ISPA di Puskesmas Talangpadang dapat disebabkan oleh faktorfaktor lingkungan yang lain seperti faktor debu, asap bakaran sampah, ventilasi rumah dll atau bisa juga disebabkan oleh faktor indvidu seperti status gizi, status imunisasi, maupun faktor prilaku misalnya orang batuk yang dekat dengan balita tidak menutup mulut sehinga dropletnya masuk ke sistem pernapasan balita dan menyebabkan balita tertular.

\section{KESIMPULAN DAN SARAN}

Berdasarkan hasil uji statistik chi square didapat nilai p-value 0,240, hal ini menunjukkan bahwa tidak ada hubungan yang signifikan antara kebiasaan merokok anggota keluarga dengan kejadian ISPA pada anak umur 1-5 tahun di wilayah kerja UPT Puskesmas Talangpadang Tanggamus.

\section{SARAN}

Bagi instansi terkait khusunya petugas kesehatan untuk terus melakukan upaya tindakan-tindakan promosi kesehatan dalam bentuk penyuluhan untuk meningkatkan pengetahuan tentang faktor resiko dan cara pencegahannya penyakit ISPA agar dapat menekan angka kesakitan ISPA diwilayah kerja Puskesmas Talangpadang.

Bagi masyarakat disarankan agar dapat meningkatkan kesadaran diri akan pentingnya kesehatan dan berperan aktif untuk mendukung program-program pemerintah dalam meningkatkan derajat kesehatan dengan cara mencari informasi dan meningkatkan pengetahuan terkait kesehatan khususnya tentang faktor penyebab ISPA

\section{DAFTAR PUSTAKA}

Ahyanti, M., \& Artha, B. S. D. (2013). Hubungan Merokok Dengan Kejadian Ispa Pada Mahasiswa Politeknik Kesehatan Kementrian Kesehatan Tanjungkarang. Kesehatan Masyarakat Andalas, 7(2).

Apriza, \& Neneng, F. N. (2018). Survey Sanitasi Lingkungan Penderita Common Cold Di Kabupaten Kampar. Ners, 2(2), 27-42.

Ardianto, Y. D., \& Yudhastuti, R. (2012). Kejadian Infeksi Saluran Pernapasan Akut Pada Pekerja Pabrik. Kesmas, 6(5), 231-233. 
Dewi, A. A. A. S., Rini, N., Rasmaya Nir Uri, Suherman, F. S., \& Triyasa, I. P. (2013). Penentuan Streptococcus Group A Penyebab Faringitis Pada Anak Menggunakan Mcisaac Score Dan Rapid Antigen Detection Test (Radt) Dalam Upaya Penggunaan Antibiotika Secara Bijak. Biologi, Xvii(1), 6-9.

Dinkes, P. L. (2016). Profil Kesehatan Provinsi Lampung 2015.

Dinkes, P. L. (2017). Profil Kesehatan Provinsi Lampung 2016.

Dinkes, P. L. (2019). Kebijakan Ispa Lampung.

Eka, R. M. (2016). Terapi Herbal Dan Alternatif Pada Flu Ringan Atau Ispa Non-Spesifik. Kesehatan, 1(2), 7-10.

Fajar, R., \& Pustaka, P. T. B. (2011). Bahaya Merokok: Pt Balai Pustaka (Persero).

Fillacano, R. (2019). Hubungan Lingkungan Dalam Rumah Terahadap Ispa Pada Balita Di Kelurahan Ciputat Kota Tangerang Tahun 2013.

Graharti, R. (2013). Hubungan Intensitas Paparan Asap Rokok Dengan Kapasitas Vital Paru Anak Sebagai Perokok Pasif Pada Siswa Kelas V Dan Vi Sd Negeri 3 Sumur Putri. Digital Repository Unila, 12.

Hadisaputra, S., Luzi, S., \& Ridho, A. (2015). Faktor-Faktor Yang Berhubungan Dengankejadian Ispa Berulang Pada Balita Usia 36-59 Bulan Di Puskesmas Kecamatan Cipayung. Bidang IImu Kesehatan, 5(1), 345-353.

Hayati, R. Z. (2017). Hubungan Konsentrasi Pm10 Faktor Lingkungan Dalam Rumah Dengan Keluhan Infeksi Saluran Pernapasan Akut (Ispa) Pada Balita Di Puskesmas Rawa Terate Kecamatan Cakung 2017.

Hidayati, I. R., Dewi Pujiana, \& Fadillah, M. (2019). Pengaruh Pendidikan Kesehatan Terhadap Pengetahuan Dan Sikap Siswa Tentang Bahaya Merokok Kelas Xi Sma Yayasan Wanita Kereta Api Palembang Tahun 2019. Kesehatan Pena Medika, 12(2), 125-135.

Irawa, T. (2015). Kajian Kualitas Lingkungan Terkait Kejadian Ispa Di Kelurahan
Simbang Kulon Kecamatan Buaran Kabupaten Pekalongan. Kesehatan Pena Medika, 5(1), 84-95.

Jalil, R., Yasnani, \& Sety, L. O. (2018). FaktorFaktor Yang Behubungan Dengan Kejadian Ispa Pada Balita Di Wilayah Keja Puskesmas Kabangka Kecamatan Kabangka Kabupaten Muna Tahun 2018. Kesehatan.

Kemenkesri. (2018). Data Dan Informasi Profil Kesehatan Indonesia 2017.

Mariza, A., \& Trisnawati. (2015). Faktor-Faktor Yang Berhubungan Dengan Terjadinya Ispa Pada Bayi (1-12 Bulan) Di Wilayah Kerja Puskesmas Rajabasa Indah Bandar Lampungtahun 2013. Kebidanan, 1(2), 57-62.

Maryunani, A. (2014). Ilmu Kesehatan Anak. Jakarta: Cv Trans Infi Media.

Milo, S., Ismanto, A. Y., \& Kallo, V. D. (2015). Hubungan Kebiasaan Merokok Di Dalam Rumah Dengan Kejadian Ispa Pada Anak Umur 1-5 Tahun Di Puskesmas Sario Kota Manado. Keperawatan, 3(3).

Musthafa, N., Astuti, R., \& Wulandari, M. (2017). Faktor Determinan Kejadian Ispa Pada Bayi Dan Balita Di Desa Jumo Kecamatan Kadungjati Kabupaten Grobokan. Semarang. Fakultas Kesehatan Masyarakat Universitas Muhammdaiyah Semarang.

Muttaqin, A. (2012). Buku Ajar Asuhan Keperawatan Klien Dengan Gangguan Sistem Pernafasan. Jakarta: Salemba Medika.

Notoadmodjo, S. (2010). Metodologi Penelitian. Jakarta: Rhineka Cipta.

Nursalam. (2013). Metodologi Penelitian. Jakarta: Salemba Medika.

P2ptmkenkesri. (2018). Kandungan Dalam Sebatang Rokok - Bagian 2.

Pratiwi, A., \& Elyza, G. W. (2016). Sistem Pakar Diagnosis Ispa Pada Balita Dengan Metode Certaninty Faktor. Snimed, 7, 42. 
Putra, Y., \& Wulandari, S. (2019). Faktor Penyebab Kejadian Ispa. Kesehatan, 10(01), 37-40.

Safrina. (2013). Hubungan Keberadaan Anggota Keluarga Yang Merokok Di Dalam Rumah Dengan Kejadin Ispa Pada Anak Di Rumah Sakit Umum Daerah Dr. Zainal Abidin Banda Aceh.

Somantri, I. (2012). Asuhan Keperawatan Pada Klien Dengan Gangguan Sistem Pernapasan. Jakarta: Salemba Medika.

Sugiyono. (2011). Statistika Untuk Penelitian. Bandung: Alvabert.

Suryono. (2010). Metodologi Penelitian Kesehatan. Yogyakarta: Mitra Cendikia.

Trisnawati, Y., \& Juwarni. (2013). Hubungan Prilaku Merokok Orang Tua Dengan Kejadian Ispa Pada Balita Di Wilayah Kerja Puskesmas Rembang Kabupaten Purbalingga. 6(1), 35-42.

Wheatley, L., \& Togias, A. (2015). Allergic Rhinitis. N Engl J Med, 372(5), 456-463.

Windrasmara. (2012). Hubungan Antara Derajat Merokok Dengan Prevalensi Ppok Dan Bronkitis Kronik Di Bbkpm Surakarta.

Zulakhah, S. T., Purwito, S., \& Titiek, S. (2017). Risk Factors Of Acute Respiratory Infections In Practice Area For Community Of Medical Students In Semarang. Kesmas, 11(4), 192-197. 